This is a preprint of an article whose final and definitive form has been published in West European Politics $\odot 2009$ Copyright Taylor \& Francis; West European Politics is available online at http://www.informaworld.com/openurl?genre=article\&issn $=0140$ $\underline{2382 \& \text { volume }=32 \& \text { issue }=1 \& \text { spage }=119}$

\title{
Impaling Dracula: How EU accession empowered civil society in
}

\section{Romania}

\section{Cristina Parau}

\begin{abstract}
Europeanization scholars increasingly debate when and in what ways the European Union (EU) influences domestic politics. This article adopts a 'bottom-up' design and the process-tracing method to examine the influence of the EU enlargement context over the political power of the new social movements in Romania between 2000 and 2004 when the EU acquis was being negotiated. It finds that domestic civil society empowerment resulted from the nexus of three interacting causal pathways: the Executive's desire to accede to the EU; a transnational advocacy network, which included domestic NGOs, reinforcing the Executive's anticipatory self-constraint; and to a somewhat lesser extent, the Executive's self-identification with certain elements of the advocacy network, reinforced by a general concern for their external reputation.
\end{abstract}

Keywords: central Executive, constructivism, Europeanization, NGOs, power relations, Romania, transnational advocacy coalitions. 


\section{Introduction}

Since the fall of the Communist regimes, the countries of Central and Eastern Europe (CEE) have been faced with the challenge of rebuilding their civil societies, previously crushed by the Communist Party. This they have endeavoured not only in the context of economic and political transition but also of accession to the EU. Although the EU has supported civil society development in the post-Communist accession countries, little research has investigated how domestic groups have responded, or how the enlargement context has affected their power to influence domestic policies (Pérez-Solórzano Borragán 2003; Eising 2007).

This article contributes to the ongoing challenge of theorising the impact of the EU (Vink and Graziano 2007) on civil society by tracing the causal pathways that have led to the empowerment of NGOs in Romania. It analyses domestic actors' motives, strategies, resources, discourses and socially constructed identities in order to explain how empowerment happened in two highly controversial contests over cultural and industrial policy at the beginning (2000-2001) and at the peak (2002-2003) of negotiations with the Commission (2000-2004), when the Social Democratic Party (PSD) held sway under Prime Minister Adrian Nastase and President Ion Iliescu.

A focus on domestic actors is called for, as they have been neglected in research on East Europeanization generally in favour of a focus on accession conditionality and the transfer of formal EU rules (for an exception see Hughes et al. 2004). And yet it is known that in the context of CEE, especially, domestic actors' preferences and interests matter more than formal institutions. The latter are still 'far from fixed' and have only limited socialising effects (Goetz 2005). Indeed conditionality and EU rules have proved so 
malleable that CEE elites with conflicting agendas have been observed to use them as 'ammunition' against each other in domestic contests (Fowler 2001; Parau 2004), indicating that domestic actors deserve more attention.

Particular heed is given in this article to discourses, which have lately become more prominent in the Europeanization literature (Schmidt and Radaelli 2004). Discourses are a cognitive phenomenon whose incidence is at the initiative of domestic actors, unprompted by Brussels. The strategic construction of discourses featuring the EU became so pervasive in Romania that local commentators called it a 'psychosis'; thus hinting how essential new discourses may be to post-Communist countries, where all political actors suffer severe material, cognitive and legitimacy deficits.

The bottom-up approach (Radaelli and Franchino 2004) employed here aims to be exploratory, to discover causal pathways that might help to explain how Europeanization has changed domestic behaviour in ways that may have been overlooked by deductive, top-down theorisation (Dimitrova 2004; Schimmelfennig and Sedelmeier 2004). The method of process tracing is resorted-to so as to untangle with more nuance and exactitude complex causal connections between the domestic, the transnational and the European. Bottom-up design and process tracing should help avoid some of the pitfalls encountered by Europeanization research (Haverland 2005). These include the difficulty of isolating 'the EU' as a distinct variable from other factors like globalisation (Goetz 2001); mistaking correlation for causation (Featherstone 2004); and focussing on only that empirical evidence which supports preconceived EU mechanisms (Radaelli and Franchino 2004). 
This article will not limit itself to the role of accession conditionality in theorising causation, the usual approach to Europeanization in the East (e.g. Grabbe 2003). So narrow a focus would not have captured the manifold of causes that contributed to empowering Romanian civil society before it enjoyed full access to EU political opportunities. The concepts of 'Europe' and of 'the EU enlargement context' enabled a broader look at the actors and institutions lying beyond Brussels centre, particularly trans-national alliances across EU member-States. Because domestic actors can step beyond even Europe to empower themselves, and because international institutions provide further opportunities, interactions between the international and the European and domestic were also traced (cf. Anderson 2003:39). Such an approach aspires to broaden the theoretical scope of empirical research in the field of Europeanization, which in the realm of new social movements has neglected 'the linkages between European and international policy networks' (Eising 2007:178).

The cases studied were selected for their controversial nature, as this yielded a richer density of data - essential to a fuller understanding of Europeanization. Controversy attracts documented attention, at home and abroad, and this tended to minimise evidentiary gaps. This criterion, however, entailed a selection bias toward atypical cases, which in turn may have biased the outcome; for example, toward ignoring, perhaps, more subtle forms of Europeanization like incremental normative change (cf. Schimmelfennig et. al 2005:34). To compensate for this shortcoming, the causal pathways are traced diachronically to enhance detection of changes in actors' resources or their learning from one controversy to the next. 


\section{A weak civil society versus a strong Executive}

The political contests analysed herein pitted a powerful Executive against a weak civil society, which in Romania, in contrast to other CEE countries, emerged for the first time only after 1989, advocating environmental and cultural heritage protection as well as democratic values. Indeed Romania experienced nothing like Solidarity in Poland (Kubik 1994); the Communist Party tolerated only civil society organisations created from the top-down by the Party itself (Linz and Stepan 1996). As in other post-Communist countries, civil society development in Romania after 1989 too was stifled by multiple factors: a preference for informal networking and a mistrust of formal organisations; material poverty; public demoralisation; distrust of domestic institutions, which failed to deliver the promised well-being; and a lack of support by the State (Howard 2003; Welch 2004).

At the beginning of 2000 - when the first case studied herein also began - Romanian NGOs were poor in human and financial capital in most areas, including internal organisational management and fundraising. Most were active only at the local level; only a few at regional, national or international levels. Most involved themselves in small-scale projects delivering social services like health care or child protection, or raising public awareness of issues little understood in Romania, e.g. environmentalism, minority and human rights, the rule of law, and governmental accountability (Epure et al. 2001; Freedom House 2004). Few had any policy expertise or knowledge of Romanian public administration, and even fewer were trying to influence public policy (Kruger and Carius 2001; author's interview with CENTRAS 2003). Even on the eve of accession, Romanian civil society with few exceptions was reported to 'remain generally weak and 
etiolated, partly due to overdependence on donor funds' (Nicholson of Winterbourne 2006:64), lacking 'the ability to mobilize attention from the opposition and the international community' (Carey 2004:593).

By contrast, the Romanian Executive during Nastase's tenure was exceptionally powerful. The coalition with Romania's Hungarian-minority party, combined with a deeply fragmented opposition, gave the PSD control over Parliament. The Nastase government routinely exploited the Executive's constitutional prerogative to rule by Emergency Ordinance, enabled all the more by PSD influence over the Constitutional Court; and over the media, either through outright ownership or through indebtedness to banks controlled within the Party's inner circle (Mungiu-Pippidi 2005). Moreover, no elites were left within the PSD yet outside the Cabinet who could act as veto-points. This vacuum of checks and balances yielded near-plenary discretion to Nastase. Other than the need to be re-elected, his government's power was constrained only by their operating in an environment of limited resources; by their determination to integrate Romania into the EU and NATO (Mungiu-Pipidi 2006); and by their strong desire to convert their identity from 'unreconstructed Communists' (Vachudova 2004:272) with 'authoritarian and populist tendencies' into a European-style Social Democratic party (Ciobanu and Shafir 2005). And yet, in the event, the NGOs rolled back the Executive's projects to become the empowered ones. The question posed is how this could have happened, and what role the EU played in it.

Civil society empowerment is thus herein defined strongly and relative to Executive power. Civil society will have been empowered if they prevail upon the Executive, that is, if their preferences are reflected in the final outcomes of domestic political outcomes, 
when otherwise they would have been disregarded (cf. Lukes 1974). A fortiori they will have been empowered to those lesser degrees often theorised in the literature, such as transnational mobilisations (e.g. Marks et al. 1996). Though not signifying nothing, these lesser forms of empowerment do not always shape outcomes (Jeffrey 2000).

In the next section, an overview will be furnished of the debates over the mechanisms through which the EU and other international actors are known to influence the behaviour of domestic actors. The third and the fourth sections present the empirical evidence. The conclusion abstracts from the case studies the bottom-up causal pathways that led to a constrained Executive and empowered NGOs.

\section{The EU, transnational networks and domestic change}

The debate over how external actors affect the behaviour of domestic actors is especially relevant to this article. Two types of 'causal mechanisms' - rationalist and sociological may be identified in the literature (Börzel and Risse 2003). Theorised within a rationalchoice framework, the EU is a new 'opportunity structure' or a cognitive and material resource for domestic actors that they may utilise strategically to achieve and/or legitimise domestic goals (Marks and McAdam 1996; Imig and Tarrow 2001; Dyson and Goetz 2003; Jacquot and Woll 2003; Thatcher 2004). Seen from the bottom-up, even 'top-down pressures' from Brussels such as accession conditionality may constitute an exploitable opportunity (Goetz and Hix 2000).

Empirical research into EU member-States has found that their interest groups and social movements have been taking advantage of the new opportunity structure created by the EU (Eising 2007). Domestic NGOs, for example, have been found to alert EU organs to their recalcitrant governments' non-compliance with the acquis, sometimes bringing 
about otherwise unlikely domestic policy outcomes (Kimber 2000; Fairbrass and Jordan 2001). The capacity to take up EU opportunities appears to be conditioned upon domestic factors, some of which facilitate while others constrain. NGOs appear likelier to resort to the EU when the domestic opportunity structure remains closed (Fairbrass and Jordan 2001), as is often the case in CEE (Rucht 2001; Tarrow and Petrova 2007). Yet lack of material and cognitive resources may hamper resort; other domestic factors may also constrain, such as 'inherited institutions and ideologies' and 'belief structures' (Marks and McAdam 1996:258). In such cases, domestic NGOs, to be rendered capable of exploiting their opportunities, may depend on transnational norm entrepreneurs and advocacy networks (Chilton 1995; Keck and Sikkink 1998; della Porta and Tarrow 2005) bound together by shared beliefs and values (Keck and Sikkink 1998). Such networks mobilise resources in support of domestic groups and 'pressure policy-makers to initiate change by increasing the costs of certain strategy options' (Börzel and Risse 2000:9). They may challenge domestic governments whose acts are not in line with EU or international norms, by alerting the parties signatory and the domestic public to the government's non-compliance (Risse and Sikkink 1999).

The sociological/constructivist mechanisms of Europeanization features intangibles like persuasion, social influence, socially constructed identities and social learning (Checkel 1999b; Börzel and Risse 2000). Those domestic actors who alter their behaviour to conform to EU or international norms and values may be expected to be empowered. Domestic actors change behaviours because they desire to become 'members of an international society' (Finnemore and Sikkink 1998:902). Social pressure from transnational norm entrepreneurs and advocacy coalitions may play a role here (Checkel 
1999a) by 'persuad[ing] [domestic] actors to redefine their interests and identities, engaging them in processes of social learning' (Börzel and Risse 2000:9). Or, behavioural change may result because domestic actors 'internalise' EU or international norms and values ('elite learning') without having to be pressurised (Checkel 1999a). When 'the state sits apart and exercises considerable control over society' (as it is still the case in many post-Communist countries) behavioural change is more likely to take place through elite learning than social pressure (Checkel 1999a:89).

Whether any of these mechanisms have affected the political power of domestic NGOs in post-Communist accession countries is a question little researched, the findings of which are contradictory (Andonova 2004; Rybáŕ and Malová 2004; Hicks 2004; Tarrow and Petrova 2007). Some have found evidence of strengthened civil society influence over their Executive as a result of EU accession (Fink-Hafner 1998); others, however, have concluded that such influence ranges from 'negligent to non-existent', despite international support (Mendelson 2002:233). Some scholars have suggested that transnational networks have shaped civil society even more than supranational (viz. EU) norms have (Fagan 2004; Bruszt and Stark 2003) but the consequences of this for domestic power relations have yet be to investigated. The evidence of how the EU has impacted CEE civil society is thus meagre and inconclusive. Moreover, research often fails to establish a clear causal link between the observed domestic effects and the theorised causes. 


\section{The influence of transnational advocacy networks}

The status quo

Shortly after winning the 2000 elections, the PSD vowed to revive Romania's once proud but now moribund tourism industry (Romanian Government 2001). In secret, the Tourism Ministry planned a Dracula theme park, to be built near the mediaeval town of Sighisoara in Transylvania. The public heard nothing until July 2001, when an Executive Emergency Ordinance formalised implementation, justifying itself by express reference to the urgency of rehabilitating Sighisoara's citadel. This the World Heritage Committee (WHC) of the United Nations Educational, Scientific and Cultural Organization (UNESCO) had estimated would become totally degraded within 50 years (Romanian Government 2001). Renowned for its authentic $12^{\text {th }}$ century architecture, Sighisoara had been inscribed as a World Heritage Site in 1999 under the UN World Heritage Convention. Except as the birthplace of Vlad the Impaler, the $15^{\text {th }}$-century ruler who inspired Bram Stoker's 'Dracula' - a claim unsubstantiated by credible evidence Sighisoara was not associated with the legend the new government was so keen to exploit (Constantinescu 2001).

The Tourism Minister envisioned a 'mega-park' built around the Hollywood Dracula, estimating tourism would surge from 10,000 to 800,000 visitors a year, bringing much needed treasure (Romanian Government 2001; Wold Heritage Committee 2002). The prospect of jobs and a higher standard of living appealed to the locals, who welcomed the plan enthusiastically (author's interview with Sustainable Sighisoara 2005; WHC 2002). The 120-hectare Park would overlook Sighisoara from the Breite Plateau (offered gratis to the Tourism Ministry by eager local authorities), whence visitors would be shuttled by 
chairlift to the citadel (Douglas-Home 2001). Breite, however, hosted an ecological treasure, a 400-year-old oak forest which Parliament had declared a nature reserve by Act 5/2000 on Protected Areas, forbidding development thereon. Building Dracula Park would entail bulldozing much of the forest, disfiguring the reserve beyond recovery (author's interview with UNESCO 2006).

\section{Domestic opposition springs up}

Mass tourism on a nature reserve next to a World Heritage Site sparked a controversy, eventually to overspill Romania's borders, when a handful of local protestors rose in opposition. The spark was lit by Bruno Fröhlich, the local Lutheran pastor, who, motivated by his Protestant ethic, petitioned the city council to eschew an 'atmosphere beneficial to "evil spirits", which Dracula Park threatened to promote' (Fröhlich 2003). The authorities ignored him, as he himself had expected (author's interview with Fröhlich 2005). Although covered by the local newspaper, this first protest inspired nobody except Alex Gota, a local environmentalist already worried about Breite Plateau. These two 'entrepreneurs', acting at their own initiative, teamed up to stop Dracula Park. Their values, starkly contrasting with those of the local populace and government, proved a better fit with those of external actors defending environment and cultural heritage.

Like Romanian civil society generally, Fröhlich and Gota lacked either resources or experience to organise an effective campaign. Only a few friends and relatives signed their protest petition (author's interview with Gota 2006). Nationally, only the ProEurope League, a civil rights group promoting EU values, responded. The League perceived a threat to the Romanian and Saxon cultural patrimony, to the environment, and to democracy and the rule of law (Pro-Europe League 2001). Other civil society 
remained unmobilised and unreliable, including, surprisingly, environmental organisations, who confined themselves to private letters of support (author's interview with Gota 2006).

The opposition to Dracula Park surprised the Executive, both local and central. They feared the protestors, who had begun to receive coverage by the German press, risked deterring foreign investors and tourists (letter of the Romanian Tourism Ministry to the Association of Ethnic Germans of Sighisoara 2001). Fröhlich and Gota fell under a torrent of verbal abuse. The Mayor of Sighisoara summoned them to render an account, demanding 'Who are you representing?' and 'Who pays you?' He bluntly declared they were under surveillance by the secret police "because they were opposing a governmental project ... subverting State power' (Fröhlich 2003). The Park Manager publicly called Fröhlich 'a nutcase'; others called him a spy because being ethnic German he maintained regular contacts in Germany (author's interview with Fröhlich 2005). Even the Tourism Minister joined in, threatening Gota with a lawsuit (author's interview with Gota 2006).

\section{Transnational civil society intervenes}

The authorities' hostility and the inadequacy of Romanian NGOs moved the protestors to seek allies outside Romania. The first to empower them were German environmentalists, who inspired 'Sustainable Sighisoara', a civic organisation founded by Gota and Fröhlich to promote sustainable development (author's interview with Fröhlich 2005). Reinforced by a smattering of local intellectuals, Sustainable Sighisoara proceeded to lobby domestic and international organisations to help persuade the Tourism Ministry to relocate Dracula Park. The discourses they constructed featured integration and the European identity that Romanian elites kept claiming for themselves: 'The Government is forever declaring that 
its first priority is integration into Europe; if so, it should refrain from any act that might taint the European cultural heritage ... [it] should be in the vanguard of any campaign aimed at protecting this ... the cultural heritage in Transylvania is our evidence that we belong to the European cultural space' (Pro-Europe League 2001). Europe was evoked to threaten the Romanian government, while motivating Brussels and other international bodies to 'give [the government] a signal' that Romania's accession might suffer (author's interview with Gota 2006).

The next transnational intervener was The Mihai Eminescu Trust (MET), a London-based charity dedicated to protecting Romania's cultural heritage by 'heading off the wrong sort of development' (author's interview with UNESCO adviser 2006). Under the patronage of Charles, Prince of Wales, and of Romanian Prince Serban Cantacuzino, an émigré architect in London advising UNESCO, the MET was much stronger than Romanian NGOs. They shared Sustainable Sighisoara's vision of development centred on traditional agriculture, crafts and ecological tourism. Their investigations had convinced them that the prospects for jobs and tourists had been exaggerated, and that Sighisoara lacked the transportation and hospitality infrastructure needed for mass tourism (MET 2002). Although motivated exclusively by its own agenda, MET empowered Sustainable Sighisoara with ideas, information and strategies (author's interview with Gota 2006). Yet MET was also empowered by Sustainable Sighisoara - with a constant flow of local information and, more importantly, with a toehold of domestic legitimacy, without which MET might have come across peremptory and foreign (author's interview with Sustainable Sighisoara 2006). 
MET was particularly effective in creating negative publicity about Dracula Park in Britain. Well-connected to the British press, MET published articles in several broadsheets, which the Romanian press re-published. This was thought to be 'incredibly important' for the Romanian Executive at a sensitive time in the accession process, when allies and patrons were needed the most (author's interview with MET 2006). MET also played a pivotal role in involving other, decisively powerful interveners, including the WHC, the superintendent of the World Heritage Convention; then the Culture Committee of the European Parliament (EP); and finally Prince Charles.

Responding to the opposition's lobbying, in March 2002, WHC dispatched a mission to Romania to investigate matters at Sighisoara and to try and persuade the Romanian government to give up its plans. This having failed, the mission left Romania threatening to put Sighisoara on the List of World Heritage in Danger. This would have blocked UNESCO funding and precluded Romania's future nomination of sites. Constraining itself somewhat, the Romanian government modified certain obtrusive features reluctantly, a reluctance stemming partly from their perception of the WHC as 'an informal group' powerless to coerce sovereign Romania (Adevarul 2002). And in fact, the WHC could muster no worse sanction than to shame the government before the international community for contempt of its own cultural heritage (author's interview with UNESCO adviser 2006).

But non-compliance might also signal contempt for the rule of law, reflecting on Romania's accession-worthiness (author's interview with Pro Patrimonio Trust 2006). WHC hinted that censure would be invoked at its next meeting in June 2002. This threat did have an impact: the Cabinet began to fear provoking Brussels, as the Commission had 
already warned that accession conditionality entailed compliance with all international conventions to which Romania was a party (author's interview with DG Enlargement 2005). The Executive's perception that Dracula Park might upset Brussels was played up by Cantacuzino, who headed UNESCO's Mission to Sighisoara in the spring of 2002, and by opposition discourses linking the World Heritage Convention to EU accession, published by the Romanian and British press.

Norm entrepreneurs lobby the EU

Brussels intervened next, in the person of Mercedes Echerer, an Austrian Green Member of the European Parliament (MEP), who sat on and, throughout the controversy, lobbied the EP Culture Committee to intervene. Echerer was drawn in by Greenpeace, of which she was a former director, which had publicly condemned Dracula Park without actively joining the campaign (author's interview with Gota 2005). Aware of the Committee's lack of jurisdiction, Echerer nevertheless calculated that the Nastase government - keen to accede and already experiencing accession woes - would 'feel under pressure' from Brussels. Apprehension that the Sighisoara site might 'disturb' the accession timetable would constrain Romania a step further (author's interview with Echerer 2005).

The Committee wrote a letter to Bucharest that deployed discourses implying delayed accession and damage to reputation, while promising rewards like funds for rehabilitating Sighisoara (Pro-Europe League 2002). The letter cited the World Heritage Convention, which an EP Resolution (16/2001) had incorporated into the acquis, and called upon Nastase 'to suspend all work that had already begun on the designated site and wait for the decision of UNESCO in June 2002' (Pro-Europe League 2002). The letter broadly hinted that 'UNESCO's ideas and concerns do have an influence on the European level' 
(author's interview with Echerer 2005). In relying on the UN to buttress its authority, the Committee may have reciprocally empowered the UN. Nevertheless, like UNESCO's, the Committee's intervention did not decisively move the Cabinet to relocate (author's interview with Echerer 2005).

Strategy and identity: the Executive constraints itself

The last intervener and, according to most observers, the decisive one was Prince Charles, heir to the British throne, who visited Transylvania privately in May 2002, likely at the instance of MET (author's interview with Pro Patrimonio Trust 2006). His itinerary included Sighisoara, whence he telephoned Romanian President Ion Iliescu, known for harbouring doubts about the Park. Charles reportedly urged sustainable development as more suitable (BBC 6 May 2002; author's interview with MET 2006). His intervention had an immediate effect: the next day Iliescu declared that Romania was 'open to all suggestions' and that the project 'will not be implemented blindly' (author's interview with MET 2006). A few days later, even Cabinet members were hinting that Dracula Park might be re-sited (Purcareanu et al. 2002). Within a month Price Waterhouse Coopers (PWC) of London had been contracted to compare Sighisoara with other sites. So soon as PWC reported, Sighisoara was abandoned. PWC had rated it second-best on the grounds that a project opposed by UNESCO and built over a nature reserve would deter foreign investors (Popa 2002).

The last in a series that had gradually constrained Nastase and his government, Prince Charles's intervention was decisive (author's interview with Pro Patrimonio Trust 2006). A strong supporter of Romania's interests, he was perceived as 'fabulous public relations for Romania' (author's interview with Pro Patrimonio Trust 2006; see also BBC 
Romanian 2006). An Executive snub might alienate his goodwill; crucially for the Cabinet, some even feared it might turn him against Romania's accession to the EU and NATO (author's interview with Pro Patrimonio Trust 2006). Britain was one of Romania's few staunch accession patrons, giving 'essential and very consistent support'; thus, Nastase was keen to preserve a 'special relationship' (author's interview with MET 2006). Even supposing that Dracula Park was too small for Britain to abandon Romania over, the government calculated nonetheless that the risk of alienating the monarch-to-be was unaffordable.

And yet, Charles's authority also rested on Romanians' anxiety to keep his friendship for its own sake. Prince Charles is greatly appreciated in Romania for his 'Romania-philia', which many observers believe had 'a big effect' (author's interview with Pro Patrimonio Trust 2006). Known to have a 'soft spot' for Transylvania's Saxon villages, monasteries and countryside, Charles through MET has funded conservation projects there (Modreanu 2002). His sheer prestige in the Romanian mind empowered him in swaying the government (author's interview with Pro Patrimonio Trust 2006). Thus Romanian Executive elites may have already become half-socialised within the international community to which Charles belonged, their identification with whom caused them to 'inhibit themselves'. Even so, Charles' authority was ultimately a Romanian social construct, for in Britain he is generally regarded as powerless.

PWC was commissioned with the 'anticipated result' that Sighisoara would be rated suboptimal - a face-saving strategy the Cabinet utilised to 'extricate' itself from the project, once it became clear that going ahead would be too damaging (author's interview with Pro Patrimonio Trust 2006). The idea was suggested to the Tourism Minister, in the wake 
of Prince Charles' intervention, by the Pro Patrimonio Trust, a London-based NGO collaborating with MET, with connections inside the Romanian embassy in London and amongst Romanian elites in London and Bucharest. Like the MET, the Trust had tried and failed to persuade the Tourism Minister of the value of environmental and cultural heritage at Sighisoara; he gave in only because the Cabinet feared more accession woes (author's interview with Pro Patrimonio Trust 2006). Once the Tourism Minister could abandon Sighisoara with plausible deniability, the Trusts could relay to UNESCO that the government were 'very seriously looking for alternative sites'; this signalled WHC to soften, in reward, the censure of Romania planned for the June 2002 meeting (author's interview with Pro Patrimonio Trust 2006).

\section{The influence of accession conditionality}

Near the same time, another controversy over environmental and cultural heritage erupted in Transylvania, when the Rosia Montana Gold Corporation (RMGC), a Canadian mining company, bought a gold-mining concession in the vicinity of Rosia Montana village. In 2002 the company announced an open-cast, cyanide-leaching mining project, which won the support of the local authorities. The first organised protest to emerge comprised a few farmers and mining-engineers. Calling themselves Alburnus Maior, they were motivated by the company's precipitate buy-out of local properties before securing the necessary permits. Lacking political experience and resources, Alburnus did little more than write letters of complaint to Romanian authorities who returned no answers, or perfunctory ones; and solicit support from ultranationalist politicians of the discredited Greater Romania Party. Such inward-looking tactics undermined their campaign, until they were 
'rescued' by transnational entrepreneurs beginning in mid-2002 (author's interviews with Alburnus Maior 2005 and with Romanian National Agency for Mineral Resources 2005).

Norm entrepreneurs 'initiate' the grassroots

The first of these was Stephanie Roth, a former journalist for The Ecologist magazine. At the prompting of MET, Roth was already in Romania campaigning against Dracula Park. She and MET had come together in London at a public presentation on Romania's cultural heritage, which implied that they both belonged to a community of shared ideas, norms and values about environmental protection and sustainability for Romania.

Roth was moved by Alburnus's weakness and the abusiveness of the Romanian authorities in permitting mining in a protected area (author's interview with Roth 2005). Following archaeological discoveries of Roman and Dacic mining galleries in 1999, the local Carnic Massif and Rosia's historic centre had been declared protected as 'cultural monuments of national importance' under Act 5/2000 (Romanian Parliament 2000). But the Culture Ministry revoked this protection when it was discovered that Carnic contained the richest gold deposits in Transylvania (Piso 2007). Open-cast cyanide mining would destroy this heritage.

Roth enabled Alburnus to mount a professional protest campaign, initiating them into the ideology and methods of the Western environmental movement. Transnational alliances far beyond Alburnus's reach were forged, attracting players like Greenpeace, CEE BankWatch and MiningWatch Canada. This created an unprecedented mobilisation, at least temporarily catalysing civil society development through network campaigning (author's interview with RMGC 2005). The coalition that formed around Alburnus subsequently became the model other Romanian NGOs strove to imitate (author's 
interview with Greenpeace Romania 2005). Alburnus's campaign received unprecedented press coverage. Brought out of obscurity into the national and international arena, both Romanian and external authorities began to heed Alburnus's concerns (author's interview with Roth 2005). Had they remained invisible, the mining project would likely have been permitted with perfunctory legality (author's interviews with DG Enlargement 2005 and Greenpeace CEE 2005).

Tactics like lawsuits and lobbying, routine in the West but novel in Romania, were also imported (author's interview with Alburnus Maior 2005). Suing the State in its own courts over environmental issues was unheard-of before Rosia Montana, but transnational fundraising empowered Alburnus to employ technical experts and lawyers competent to challenge the legality and feasibility of complex projects (author's interviews with Alburnus Maior 2005 and RMGC 2005). Initiating scores of lawsuits against the company and the authorities, by 2005 Alburnus had won two important cases. One overturned the Culture Ministry's decision to annul the Carnic Massif's archaeological protection. The other voided the local Council's public consultation, which misapplied land-use law (Alburnus Maior 2004).

The transnational network taught Alburnus to circumvent Bucharest's unresponsiveness by lobbying beyond Romania (author's interviews with Alburnus Maior 2005). They lobbied the Hungarian Environment Ministry to activate the Espoo Convention on Environmental Impact Assessment in a Transboundary Context, obligating Romania to consult potentially affected neighbours before granting environmental permits like the one sought by the mining company (CEE Bankwatch 2002). Scheduled to accede to the EU before Romania, Hungary would suffer the most in case of an accident at Rosia 
Montana. An omen had occurred in 2001, when cyanide had 'spilled over' into Hungary from Baia Mare, another gold mine in north-west Romania. Still anxious, the Hungarians became actively involved in Rosia Montana.

Brussels too was lobbied in the expectation that the EU would use its leverage to pressurise the Romanian government to comply with domestic law and the newly transposed environmental acquis (author's interviews with Alburnus 2005 and DG Environment 2005). Dracula Park and other, human-rights controversies had taught the NGOs that the Romanian government, whatever its party orientation, was so sensitive to external pressures that even 'a word [from somebody influential] may be sufficient' to alter its course (author's interview with Alburnus 2004). Brussels's intervention would make the project more expensive, increasing the odds it would fail.

The transnational entrepreneurs empowered Alburnus with cognitive as well as material resources. They broadened the scope of the campaign beyond property rights and mining issues. Alburnus's founding members were not only unaccustomed but actually fearful of challenging State authority (author's interview with Roth 2005). They were made aware of their rights under Romania's new democracy: to challenge the authorities' decisions; to express their personal viewpoint; to obtain from the State information of public interest; to hold public officials accountable; and to communicate their concerns to the international community (author's interview with Roth 2005). These new ways of thinking had a profound impact on the mentality of Alburnus and their Romanian allies (author's interview with Alburnus Maior 2005).

Alburnus's dominant discourses were also re-framed to include 'sustainable' alternatives to open-cast mining: small-scale mining without cyanide, eco-tourism, agro-forestry, and 
traditional handicrafts (Bara 2002). Alburnus would have been unlikely to have conceived such discourses by itself. Downplaying private property and emphasising environmental and cultural-heritage protection broadened the campaign to appeal to other transnational interests holding the same values. Alburnus was empowered all the more because accession to the EU was changing the context of Romania's environmental policy-making.

The transnational entrepreneurs taught their Romanian allies how to whet Brussels's interest by constructing the EU rhetorically. Alburnus's discourses became centred on the tenets of accession conditionality, like respect for the rule of law, a value commonly espoused by the Commission and Parliament. These discourses combined an 'ethical' EU - made up of formal and informal norms, values, and principles - with a 'punitive' EU that would punish the Romanian government for violating accession conditionality. Intended to legitimise Alburnus before domestic and international audiences, to mobilise their support, and to threaten the government, discourses were strategically timed to coincide with junctures when the Romanian government would be especially vulnerable; for example, just before the 2004 elections (author's interview with Greenpeace CEE 2005; Reuters 2002).

Ostensibly 'informative' letters to the European Commission and Parliament were widely publicised at home, a 'sabre-rattling' strategy designed to make the government fear that 'powerful foreigners had become aware of Rosia' (author's interview with Greenpeace Romania 2005). The NGOs calculation rested on a socially constructed power asymmetry between the Romanian government and the EU. It resonated with Romanians' perceptions of the EU as a saviour who would punish corrupt and inefficient governors 
(author's interview with Alburnus's coalition 2005). It also reflected the hierarchical, authoritarian nature of Romanian society, where the stronger whips the weaker forward (as opposed to, for example, leading the weaker by example). Discourses featuring the EU had become a potent weapon for gaining relative advantage.

The Executive anticipates accession woes and constraints itself

The lobbying had the desired effect of prodding Brussels to act. Socialist and Green MEPs were the first to intervene in 2002, asking probing questions of the Romanian government and the Commission, and taking direct action with visits to Rosia (European Parliament 2004; author's interview with Echerer 2005). Albeit uncoercive, these interventions empowered Alburnus and its Romanian allies with much needed validation and moral support (author's interview with Greenpeace Romania 2005). This mattered because they had few domestic allies and played an insignificant role in environmental politics.

The first official EP delegate to visit was Mercedes Echerer, mover of the Culture Committee's intervention in Dracula Park. Her questioning constrained the Romanian authorities somewhat, as witness the Environment Minister's 'visible efforts' to convince her of their intention to respect EU environmental standards (author's interview with Echerer 2005); or the PM's sudden interest in the project, who ordered the Minister to decide the permits sooner (author's interview with Romanian Environment Minister 2005). Echerer's visit impressed Romanian officials enough to prod them to pro-act in the Rosia affair before the EU reacted negatively. In contrast to Dracula Park, which they themselves had originated and were keen to see through, the Executive was ambivalent about the Rosia project, which the previous government had initiated and whose benefits 
to Nastase's Cabinet were less clear (author's interview with Romanian Environment Minister 2005). The government was also keen to forestall yet another uproar that might draw-in transnational actors, with all the ensuing consequences - damage to reputation and external image, especially - that they had recently experienced. Dracula Park had peaked only a few months earlier, and the Baia Mare gold mining accident, which had happened the year before (2001), was still fresh in mind.

They resorted to soliciting guidance from the Commission, with the Environment Minister writing a letter to probe DG Enlargement's opinion of Rosia and its opportuneness (author's interview with Romanian Environment Minister 2005). Involving the Commission, it was thought, would yield several advantages. The government would gain assurance that their decisions over Rosia would not frustrate relations with the Commission and upset the acquis negotiations. At the same time they would enhance their credibility with the EU and burnish their external image before the Environment Ministries of the EU member-States (author's interview with senior civil servant, Environment Ministry 2005 and 2006). They would be demonstrating their willingness to co-operate, their earnestness about environmental protection, and their reliability as a future EU member-State (author's interview with DG Environment 2005). Domestically, they were hoping that the involvement of the EU would convince civil society, in particular the media, to ease off the pressure (Alburnurs Maior 2002; author's interview with Romanian Environment Minister 2005).

DG Enlargement declined to be drawn in, but there is evidence suggesting Brussels hinted informally it leaned against permitting Rosia (author's interview with DG Enlargement 2005). The threat was never explicit; the government was expected to 'read 
between the lines' that if compliance with EU law fell but a little short, or if Baia Mare happened again, Romania's credibility would be compromised and accession negotiations set back (author's interviews with DG Enlargement 2005).

By June 2003 the European Commission, having become involved in monitoring the Rosia affair, was moved to intervene by the many communications it received from Alburnus, from MEPs and from the Hungarian government (author's interview with DG Environment 2005). The Commission lacked jurisdiction to direct Romania in permitting the project, but they could demand that the mining fully complies with all applicable EU law. And because accession was in full swing, DG Enlargement could demand that Romania enforces the draft EU Directive on Mining Waste, even before the EU itself had adopted it (author's interview with DG Environment 2005). This went far beyond the Commission's authority over any member-State. In parallel DG Environment demanded that Romania allows the public to participate in all relevant decisional processes (author's interview with DG Enlargement 2005).

The Commission also resorted to informal means of influence. Rosia was put even on the tangential agendas of meetings of EU-Romanian political and technical joint bodies: EU civil servants would make a point of asking their Romanian counterparts about developments, particularly as to the environmental permits the company needed to begin operations (author's interviews with DG Enlargement and DG Environment 2005). By making Rosia a 'permanent topic of discussion', the Commission 'sent the message' that the EU was monitoring every move, so that the government, 'feeling under threat', might proceed with caution (author's interview with DG Enlargement 2005). 
The Hungarian government also weighed in. Having been stricken the hardest by Baia Mare, Hungary intervened actively in 2003, near the close of its own negotiations with the EU. Though not yet a member, Hungary was carefully heard by the Environmental Council of Ministers. Thereafter, the Council regularly questioned the Commission about Rosia, which prodded it to continue monitoring. Acceding in 2004, Hungary became even more active - and wielded a vote on closing the environmental acquis negotiations with Romania. Hungary conditioned her assent on a Romanian commitment to implement the Mining Waste Directive by 2007, to lower the risks of another cyanide spill (author's interview with DG Environment 2006).

The Romanian government adjusted by setting up bilateral commissions and working groups with Hungary to facilitate information exchange and consultation on Rosia (author's interview with Romanian Environment Minister 2005). The PSD government's solicitude was motivated not only by fear of accession difficulties, but also by the desire to preserve good relations with their Hungarian Social Democratic colleagues, who had won the most recent elections. Nastase was also known to get on with the Hungarian PM, a relationship that socialisation within the Socialist International could not but facilitate (author's interview with Romanian Environment Minister 2005). Although 'rationally choosing' to avoid sanctions, Nastase's caution was likely born, too, of influences like his self-identification with a pan-European community of Social Democrats.

The Cabinet, well aware of Brussels's disfavour and Hungary's anxiety, grew cautious, even though a few powerful Cabinet members held out for going ahead (author's interviews with DG Environment 2005 and with Romania's Negotiations Team 2006). Most Ministers came to perceive Rosia as posing 'an extraordinary political risk', 
creating 'very serious problems of image' for Romania given that 'every member state has a vote, and such things [as Rosia] matter within the entire framework of the process that will decide [Romania's accession]' (author's interview with Romania's Negotiating Team 2006). In June 2003 Nastase publicly declared that the project was no 'priority' for his government because of its high environmental risks (Alburnus Maior 2003). Following this, the gold-mining company withdrew its environmental permit application, not to re-submit it until over a year later, immediately following Nastase's loss to the Justice and Truth Alliance candidate, Traian Basescu, in December 2004.

\section{Conclusions}

Civil society's preferences for environmental protection and cultural heritage prevailed, an outcome unprecedented in contemporary Romanian politics. The expectation had been that the Executive would have implemented both projects unilaterally, heedless of minority opinion; in the event, the Executive in constraining themselves empowered that minority. Domestic civil society empowerment stemmed mainly from two causal pathways: pressure from transnational advocacy networks and norm entrepreneurs; and Executive self-constraint in anticipation of accession. The third, sociological pathway persuasion, social influence, socially constructed identities, and learning - although it did contribute, would not likely have produced the observed changes in Executive behaviour by itself.

The two main causal pathways synergised to bring the Executive to the point where it was obliged to constrain itself all the more, and in the end, decisively. At first, the network had consisted only of civil society actors who shared values but who, on their own, wielded but limited power, as some of the literature has suggested. It proved 
inadequate against a hostile Executive until its members tapped into the higher authority of other, more powerful actors. Thus was formed a transnational advocacy network that in addition to civil society involved EU officials and organs, third-party State actors, and international governmental and non-governmental organisations (cf. Sikkink 2005). All actors in this network were on some level elites enjoying little popular support. But they reinforced each other in a synergistic 'virtuous circle' linking the domestic, the European and the transnational. Transnational strengthened domestic civil society, yet was also strengthened by it. Sustainable Sighisoara and MET, for example, reciprocally empowered each other. Transnational civil society was empowered by UNESCO and the EU, while UNESCO relied on the EP's Cultural Committee (and vice versa). The whole proved more than the linear sum of its parts (for a similar finding see Kelley 2004).

The principal virtue of the civil-society norm entrepreneurs was thus to have crafted discourses and ventured lobbying that attracted like-minded political potentates, whose values and interests chimed with their own while clashing with the Romanian Executive's, and who had power to 'discipline' the Executive (cf. Radaelli and Schmidt 2004). Discourses constituted the medium through which EU authority was signalled to the Executive; conveying a vision of what constituted 'appropriate behaviour' in light of pending membership. Discursive constructions of the EU thus matter, revealing that, when examined from the bottom up, EU effects manifest themselves not only straightforwardly through top-down EU conditionality and the transfer of EU rules (cf. Schimmelfennig and Sedelmeier 2005), but also circuitously and galvanised from the bottom up (cf. Olsen 2002). 
The transnational network catalysed the other main causal pathway, which involved the Executive's strategic interests. Exploiting the positive incentives and negative sanctions implicit in accession conditionality (but seldom spelt-out), the network altered the Romanian Executive's cost-benefit calculations so as to reinforce its accessionanticipating self-constraint. Civil society empowerment sprang from the Executive's overriding desire to accede to the EU, and to be accepted into the very international community giving rise to the advocacy network that was endeavouring to constrain it. Civil society empowerment may thus be contingent upon which stage of accession the State is passing through: a hostile Executive is especially likely to constrain itself at the climax of accession negotiations, as evidenced by the Nastase government's greater reluctance to yield over Dracula Park, which fell nearer the beginning of acquis negotiations, compared to Rosia Montana which peaked at the climax thereof. This raises the question, yet to be investigated, of what happens when the influence of accession conditionality wanes.

The sociological/constructivist causal pathway also contributed to modifying Executive behaviour. Dracula Park evidences how the highest Executives in Romania were becoming engaged in transnational networks, as illustrated by how the Mihai Eminescu and Pro Patrimonio Trusts facilitated their extrication from Sighisoara. And their attempt to involve the European Commission in Rosia Montana, to enhance their credibility and burnish their external image suggests that even the identities of the most reactionary (neo-Communist) Romanian governmental elites may have begun to be reshaped. Nevertheless, it remains to be explored how deep this change has been, and how far it may be attributed, in the pre-accession phase, to the EU or to other factors. A question 
also remains about whether this pathway on its own could have sufficed to cause the observed changes in Executive behaviour.

Whether, when and to what extent the causal pathways identified above became activated depended on pre-existing domestic factors - the nature of the domestic opportunity structure, the number of veto points ( $c f$. Cortell and Davis 1996), as well as domestic actors' pre-existing interests, resources and socially constructed identities. Indeed, it was the tightly closed domestic opportunity structure that moved domestic civil society actors to resort to external opportunities - an unlikely move had their grievances been negotiable within Romania. And the advocacy network enjoyed so much constraining leverage partly because it needed to sway just a few top Executives (few veto points) to impact domestic politics significantly, due to the centralism of the Romanian State.

Domestic actors' pre-existing interests and identities mattered too. The Executive was reluctant to constrain itself in the case of Dracula, a project which they had initiated; but constrained itself much more easily in Rosia Montana, as it was not 'their' project and offered uncertain benefits. As for identity, this so constrained the local founders of Alburnus Maior, that in the beginning it did not even occur to them to lobby Europe. Mobilising over private property rights disabled them (before transnational norm entrepreneurs supervened) to network with Europe in the 'right' way. In Dracula Park, by contrast, the search for empowerment was motivated by local entrepreneurs' selfidentification with values that only a tiny minority of Romanians shared and which cannot be traced to the acquis or conditionality. Lastly, the Executive leadership's preexisting identities, viz. with Prince Charles and pan-European Social Democracy, exerted a constraining influence over their behaviour. 
As for resources, domestic civil society's dependency on transnational allies implies a prerequisite capacity to network, which constitutes a resource. But in post-Communist Romania, civil society, particularly at the grassroots level, possesses too little of this capacity, even to the point of being unaware of transnational networking or its advantages. If not for being 'initiated' proactively by their transnational allies, many domestic actors' incapacity to tap into the right networks would likely have resulted in a very different outcome - the status quo. 


\section{References}

Adevarul (2002). 'We are not worried about Dracula Park', 17 January.

Alburnus Maior (2003). ‘Romania’s Persistent Gabriel Resources Rebel: Prime Minister

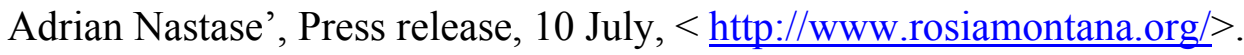

Alburnus Maior (2004) Anticipating Surprise - Assessing Risk. Investors. Guide to Gabriel Resources Rosia Montana Mine Proposal. Rosia Montana, 8 October $<$ http://www.rosiamontana.org/> (accessed 5 March 2005).

Anderson, J. J. (2003). 'Europeanization in Context: Concept and Theory', in K. Dyson and K. H. Goetz (eds.), Germany, Europe and the Politics of Constraint. Oxford: Oxford University Press.

Andonova, L. (2004). Transnational politics of the environment: the European Union and environmental policy in Central and Eastern Europe. Cambridge, Mass.: MIT Press.

Bara, A. (2002). The decision-making process for the gold mine project of Rosia Montana, Romania, MSc. thesis, Central European University, Budapest.

BBC (2002). 'Prince Opposes Dracula Park', 6 May.

BBC Romanian (2006). 'Interview with Robin Barnett, British Ambassador to Romania', 16 June.

Börzel, T. and T. Risse (2000). 'When Europe Hits Home: Europeanization and Domestic Change', European Integration Online Papers, 4.

Börzel, T. and T. Risse (2003) 'Conceptualizing the Domestic Impact of Europe', in K. 
Featherstone and C. Radaelli (eds.), The Politics of Europeanization. Oxford: Oxford University Press.

Bruszt, L. and D. Stark (2003). 'Who Counts? Supranational Norms and Societal Needs', East European Politics and Societies, 17:1, 74-82.

Carey, H. F. (ed.) (2004). Romania since 1989: politics, economics, and society. Lanham; Oxford: Lexington Books.

CEE Bankwatch (2002). 'Hungary to Invoke Espoo Convention towards Romania in Response to Proposed Gold Mine', Press release, 12 August 2002.

Checkel, J. (1999a). 'Norms, institutions, and national identity in contemporary Europe', International Studies Quarterly, 43:1, 83-114.

Checkel, J. (1999b). 'Social construction and integration', Journal of European Public Policy, 6:4, 545-60.

Chilton, P. (1995). 'Mechanisms of change: social movements, transnational coalitions, and the transformation processes in Eastern Europe' in T. Risse-Kappen (ed.), Bringing transnational relations back in. Non-states actors, domestic structures and international institutions. Cambridge: Cambridge University Press.

Ciobanu, M. and M. Shafir (2005). 'The 2004 Romanian elections: a test for democratic consolidation?', RFE/RL Reports, 7 April 2005.

Constantinescu, C. (2001). 'Sighisoara, half way between protection and valorisation', Interview with Peter Derer, Former Minister Secretary of State, 2 April 2001. $<\mathrm{http}: / /$ www.cultureroutes.lu/php/fo_index.php?lng=en\&dest=bd_ar_det\&id $=00000037>($ accessed 4 
January 2006).

Cortell, P. A. and J. W. Davis (1996). 'How do international institutions matter? The domestic impact of international rules and norms', International Studies Quarterly, 40:4, 451-478.

della Porta, D. and S. Tarrow (2005). 'Transnational Processes and Social Activism: An Introduction' in D. della Porta and S. Tarrow (eds.), Transnational Protest and Global Activism. Rowman \& Littlefield Publishers, Inc.

Dimitrova, A. (ed.) (2004). Driven to Change. The European Union's Enlargement Viewed from the East. Manchester: Manchester University Press.

Douglas-Home, J. (2001). 'Dracula goes Disney. A Transylvanian theme park with dungeons and blood-festooned tunnels could destroy a historic gem', The Times, 6 November.

Dyson, K. and K. H. Goetz (2003). 'Living with Europe: Power, Constraint, and Contestation' in K. Dyson and K. H. Goetz (eds.), Germany, Europe and The Politics of Constraint. Oxford: Oxford University Press.

Epure, C., Tiganescu, O. and Vamesu, A. (2001) Romanian Civil Society: An Agenda for Progress. A Preliminary Report on the Civicus Index on Civil Society Project in Romania. Bucharest, Civil Society Development Foundation.

Eising R. (2007). 'Interest Groups and Social Movements' in P. Graziano and M. Vink (eds.), Europeanization. New Research Agendas. Palgrave Macmillan.

European Parliament (2004). 'Written Question (E-2449/02) by Erik Meijer (GUE/NLG) to the Commission', Official Journal of the European Union, C 33 E/6 EN 


\subsubsection{4, Brussels.}

Fagan, A. (2004). Environment and democracy in the Czech Republic: the environmental movement in the transition process. Cheltenham: Edward Elgar.

Fairbrass, J. and A. Jordan (2001). 'Protecting biodiversity in the European Union: national barriers and European opportunities?', Journal of European Public Policy, 8:4, $499-518$.

Featherstone, K. (2004). 'The political dynamics of external empowerment: the emergence of EMU and the challenge to the European social model' in A. Martin and G. Ross (eds.), Euros and Europeans: monetary integration and the European model of society. Cambridge: Cambridge University Press.

Fink-Hafner, D. (1998). 'Organized interests in the policy-making process in Slovenia', Journal of European Public Policy, 5:2, 285-302.

Finnemore, M. and K. Sikkink (1998). 'International Norm Dynamics and Political Change', International Organization, 52(4):887-917.

Fowler, B. (2001). 'Debating sub-state reform on Hungary's "road to Europe”, , ESRC ‘One Europe or Several?’ Programme Working Paper 21/01, Brighton: University of Sussex.

Freedom House (2004). The Anticorruption Policy of the Romanian Government Assessment Report. Washington, D.C, Freedom House.

Fröhlich, H. B. (2003). 'Only God Can Stop Us!!! Memoirs of the Protest Against Dracula Park' (personal diary).

Goetz, K. H. (2001). 'European Integration and National Executives: A Cause in Search 
of an Effect' in K. H. Goetz and S. Hix (eds.), Europeanised Politics? European Integration and National Political Systems. London: Frank Cass.

Goetz, K. H. (2005). 'The New Member States and the EU: The Challenge of Adapting to Europe', in S. Bulmer and C. Lequesne (eds.), Member States of the European Union. Oxford: Oxford University Press.

Goetz, K.H. and S. Hix (2000). 'Europeanised Politics? European Integration and National Political Systems', West European Politics, 23:4.

Grabbe, H. (2003). 'Europeanization Goes East: Power and Uncertainty in the EU Accession Process' in K. Featherstone and C. M. Radaelli (eds.), The Politics of Europeanization. Oxford: Oxford University Press.

Haverland, M. (2005) 'Does the EU cause domestic developments? The problem of case selection in Europeanization research', European Integration Online Papers, 9:2.

Hicks, B. (2004). 'Setting Agendas and Shaping Activism: EU Influence on Central and Eastern European Environmental Movements', Environmental Politics, 13:1, 216 $-233$.

Howard, M. M. (2003). The Weakness of Civil Society in Post-Communist Europe, Cambridge: Cambridge University Press.

Hughes, J., G. Sasse, and C. Gordon (2004). Europeanization and regionalization in the EU's enlargement to Central and Eastern Europe: the myth of conditionality. New York: Palgrave Macmillan.

Imig, D. and S. Tarrow (2001). 'Political Contention in a Europeanising Polity', West European Politics, 23:4, 73-93. 
Jacquot, S. and C. Woll (2003). 'Utilisation of European Integration - Europeanisation from a Sociological Perspective', European Integration Online Papers, 7 (12).

Jeffery, C. (2000). ‘Sub-national mobilisation and European integration', Journal of Common Market Studies 38:1, 1-24.

Keck, M. E. and K. Sikkink (1998). Activists Beyond Borders. Advocacy Networks in International Politics. Cornel University Press.

Kelley, J. (2004). 'International actors on the domestic scene: membership conditionality and socialization by international institutions', International Organization 58:3, 425-457.

Kimber, C. (2000). 'Implementing European environmental policy and the Directive on Access to Environmental Information' in C. Knill and A. Lenschow (eds.), Implementing EU environmental policy: new directions and old problems. Manchester: Manchester University Press.

Kruger, C. and A. Carius (2001). Environmental policy in Romania. Towards EU accession. Berlin: Ecologic.

Kubik, J. (1994). The power of symbols against the symbols of power: the rise of Solidarity and the fall of state socialism in Poland. University Park, Pa.: Pennsylvania State University Press.

Linz, J. J. and Stepan, A. (1996) 'The Effects of Totaliarism-cum-Sultanism on Democratic Transition: Romania' in J. J. Linz and A. Stepan Problems of Democratic Transition and Consolidation. Southern Europe, South America, and Post-Communist Europe, Baltimore: Johns Hopkins University Press. 
Lukes, S. (1974). Power: a radical view. London: Macmillan.

Marks, G., L. Hooghe and K. Blank (1996). 'European integration from the 1980s: state centric vs. multi-level governance', Journal of Common Market Studies, 34:3, $341-78$

Marks, G. and D. McAdam (1996). 'Social Movements and the Changing Structure of Political Opportunity in the European Union', West European Politics, 19:2, 249278.

Mendelson, S. E. and J. K. Glenn (2002). 'Conclusion: The Power and Limits of Transnational Democracy Networks in Postcommunist Societies' in S. E. Mendelson and J.K. Glenn (eds.), The Power and Limits of NGOs. A Critical Look at Building Democracy in Eastern Europe and Eurasia. New York: Columbia University Press.

Modreanu, C. (2002). 'The Saxon villages in Transylvania in the attention of the British Royal House', Romania Libera.

Mugiu-Pippidi, A. (2005). 'Transformation Reloaded?', SAR Policy Brief, August 2005 http://www.sar.org.ro/Policy\%20memo13-en.pdf (accessed 4 June 2006).

Mugiu-Pippidi, A. (2006). Europeanization without decommunization: a case of elite conversion in D. Phinnemore (ed.), The EU \& Romania. Accession and Beyond. London: Federal Trust for Education and Research.

Nicholson of Winterbourne, E. (2006) 'Civil Society and the Media in Romania' in D. Phinnemore (ed.), The EU \& Romania. Accession and Beyond. London: Federal Trust for Education and Research. 
Olsen, J. P. (2002). 'The Many Faces of Europeanization', Journal of Common Market Studies, 40:5, 921-952.

Parau, C. (2004). 'Europeanisation as Empowerment of Civil Society: All Smoke and Mirrors?', Paper presented at the European Consortium for Political Research conference, Budapest, 10-13 September 2004.

Pérez-Solórzano Borragán (2006). 'Post-Communist Interest Politics:A Research Agenda', Perspectives on European Politics and Society, 7(2): 134 - 154.

Piso, I. (2007). 'Adrian Iorgulescu, acuzat de complicitate la dezastrul arheologic de la Rosia Montana', Romania Libera, 25 February.

Popa. C. (2002). 'The shareholders have no control over Dracula', Capital, 11 July 2002.

Pro-Europe League (2001). NO to the transformation of Sighisoara in Dracula Park, Press release, 8 November.

Pro-Europe League (2002). Scrisoarea domnului Michel Rocard, preşedintele Comisiei de Cultură a Parlamentului European.

Purcareanu, L., N. Burtan and L. Moisei (2002). 'Agathon withdraws: Dracula no longer haunts Sighisoara', Evenimentul Zilei Online, 15 May.

Radaelli, C. and F. Franchino (2004). 'Analysing Political Change in Italy', Journal of European Public Policy, 11:6, 941-53.

Radaelli, C. and V. Schmidt (2004). 'Conclusions', West European Politics, 27:2, 364 379.

Reuters (2002). 'Greenpeace Slams Canadian Gold mining project', 4 December. 
Risse. T. and K. Sikkink (1999). 'The socialization of international human rights norms intro domestic practices: Introduction' in T. Risse, S. C. Ropp and K. Sikkink (eds.), The Power of Human Rights: International Norms and Domestic Change. Cambridge: Cambridge University Press.

Romanian Government (2001). 'Reasons for Emergency Ordinance 3/2001 approving and implementing the Special Tourism Development Program for Sighisoara', Romanian Parliament, <http://www.cdep.ro/proiecte/2001/400/10/1/em411.pdf > (accessed December 2004).

Romanian Parliament (2000). Parliamentary Act 5/2000 regarding the approval of the Land-Use Plan of the National Territory. Section III - Protected Areas. Annex III.

Rucht, D. (2001). 'Lobbying or Protest? Strategies to Influence EU Environmental Policies in D. Imig and S. Tarrow (eds.), Contentious Europeans, Protest and Politics in an Emerging Polity. Rowman \& Littlefield Publishers, Inc.

Rybár, M. and D. Malová (2004). 'Exerting influence on a contentious polity: the European Union's democratic conditionality and political change in Slovakia' in A. Dimitrova (ed.), Driven to Change. The European Union's Enlargement Viewed from the East. Manchester University Press.

Schmidt, V. and C. Radaelli (2004). 'Policy Change and Discourse in Europe: Conceptual and Methodological Issues', West European Politics, 27:2, 183 - 210.

Schimmelfennig, F. and U. Sedelmeier (2004). 'Governance By conditionality: EU rule transfer to the candidate countries of Central and Eastern Europe', Journal of European Public Policy, 11:4, 661-679. 
Schimmelfennig, F. and U. Sedelmeier (2005). 'Conclusions: The Impact of the EU on the Accession Countries' in F. Schimmelfennig and U. Sedelmeier (eds.), The Europeanization of Central and Eastern Europe Cornell University Press.

Schimmelfennig, F., S. Engert and H. Knobel (2005) 'The Impact of EU Political Conditionality' in F. Schimmelfennig and U. Sedelmeier (eds.), The Europeanization of Central and Eastern Europe Cornell University Press.

Sikkink, K. (2005). 'Patterns of Dynamic Multilevel Governance and the InsiderOutsider Coalition' in D. della Porta and S. Tarrow (eds.), Transnational Protest and Global Activism. Rowman \& Littlefield Publishers, Inc.

Tarrow, S. and T. Petrova (2007). 'Transactional and Participatory Activism in the Emerging European Polity. The Puzzle of East-Central Europe', Comparative Political Studies, 40:1, 74 - 94.

Thatcher, M. (2004). 'Winners and Losers in Europeanisation: Reforming the National Regulation of Telecommunications', West European Politics 27:2, 284 - 309.

The Mihai Eminescu Trust (2002). 'Letter summarising the outcome of the meeting with Agathon', 26 June 2002.

Vachudova, M. A. (2005). Europe Undivided: Democracy, Leverage, and Integration after Communism. Oxford: Oxford University Press.

Vink, M. and P. Graziano (2007). 'Challenges of a New Research Agenda' in P. Graziano and M. Vink (eds.), Europeanization. New Research Agendas. Palgrave Macmillan.

Welch, S. (2004) 'Democracy without Civil Society?', International Studies Review 6:2, 
306-308.

World Heritage Committee (2002). 'Report of the UNESCO-ICOMOS Joint Mission to Romania', 22-28 March 2002 (WHC-02/CONF.202/INF.11), Paris: World Heritage Committee. 


\section{Address for correspondence}

Dr. Cristina Elena Parau, Centre for Socio-Legal Studies, University of Oxford, Manor Road, Oxford, Manor Road, OX1 3UQ, 01865284247, cristina.parau@csls.ox.ac.uk.

\section{Acknowledgements}

I would like to thank all of my interviewees, who carved out precious time to answer my detailed and sometimes intrusive questions; the Ratiu Family Foundation and the Central Research Fund, who contributed toward the funding of this research; while giving special thanks to Dr. Gwendolyn Sasse, Prof. James Hughes, Prof. Klaus H. Goetz, Prof. Laszlo Bruszt and two anonymous referees for their valuable comments on earlier drafts of the article.

\section{Biographical note}

Cristina Elena Parau is currently a British Academy Postdoctoral Fellow at the Centre for Socio-Legal Studies, University of Oxford. She earned a Doctorate in Government at the London School of Economics in 2007. She has a MSc. in Environmental Change from Brunel University (UK) and a BSc. in Ecology from 'Lucian Blaga' University (Sibiu, Romania). 